\title{
OUTLOOKS FOR THE LEGAL FRAMING OF PARADIPLOMACY: THE CASE OF BRAZIL
}

\section{by Marinana Andrade e Barros}

International Law Center Brasil, Brasil

Email: marinana andrade@yahoo.com.br

\begin{abstract}
The last decades have seen a deepening of paradiplomacy which is an especially important phenomenon for the federal states. This development became a source of change in the constitutions of federal states in order to trace prospects and limits for such process. Brazil is part of the group of states where non-central governments reaching beyond the national borders have occurred without a legal framework specific to the issue. In a federal state known for its centralization like Brazil such discussion can be harsh but its relevance to local and regional development and to the balance of the federative pact turns is necessary.
\end{abstract}

Keywords: Paradiplomacy, Brasil, federalism. 


\section{About Federal Governance}

Federal Governance is an online graduate journal on theory and politics of federalism and multilevel governance. Its mandate is to engage the global federalism community and reach out to outstanding graduate students interested in federalism and multi-level governance. By providing a platform for graduate students to have early success in their careers, Federal Governance seeks to promote and sustain interest in federalism and multi-level governance research among graduate students. Allied with the Forum of Federations and founding partner, Institute of Intergovernmental Relations at Queen's University; Federal Governance aims to contribute to a global dialogue on federalism.

Co Chairs, Advisory Committee:

Publisher:

Managing Editor:

Associate Editors:

\section{Rupak Chattopadhyay and Christian Leuprecht}

Forum of Federations

(Rupak Chattopadhyay and Rod Macdonell)

Annegret Eppler

Joshua Cerovski, Dominic Heinz,

Eva-Maria Maggi and Victoria Tait

\section{Terms of Use}

Your use of this Federal Governance article indicates your acceptance of Federal Governance's Terms and Conditions of Use, available at www.federalgovernance.ca/terms. Federal Governance's Terms and Conditions of Use provides that you may use Federal Governance content only for personal, academic and non-commercial use. Each copy of any part of this Federal Governance article must contain the same copyright notice that appears on the screen or printed page of such transmission. 


\section{Introduction}

Recent years have seen a deepening of studies on the international action of the socalled sub-national ${ }^{1}$ governments. It is an especially important phenomenon for federal states, since existing democratic regimes and federalism as a form of the state are considered relevant internal factors for the development of international relations of subnational governments (Vigevani 2006). Therefore, although it is not a phenomenon unique to federal states, the international insertion of non-central government has developed with some frequency and success in this form of state which makes this a relevant theme for the understanding of the contemporary contours of federalism.

This development has meant that some federations have adapted their legislation to draw up the perspectives and limits of the international action of sub-national governments. Brazil is part of a group of states where non-central governments, reaching beyond the national borders, have formed without a legal framework dictating the process. This article seeks to understand how Brazilian national legal regulations have dealt with this phenomenon and how the process of legal framing of paradiplomacy is developing to meet the challenges this trend engenders.

Initially, I analyze the actions of sub-national governments in international development, concentrating specifically on the causes themselves and their growth. Then the tendencies of the constitutionalization of the international relations undertaken by sub-national governments will be examined, before moving on to review the efforts to make it part of the law system in Brazil. Finally, I review the consequences of un-constitutionalized paradiplomacy.

\section{The Development of Paradiplomacy}

Paradiplomacy refers to international action by non-central governments ${ }^{2}$ (Soldatos 1990). ${ }^{3}$ Widespread international action of federal entities began before the 1970 s and 1980s. Explanations for this development range from factors internal to federations through to aspects acquired by the international system in recent decades (Keating 1999, Romero 2004).

Within federal states the drivers of paradiplomacy often include the division of competencies and autonomy given to sub-units through federative pacts. The need for members of the federation to fulfill competencies laid out by Constitutional charters

1 Academically, it would be correct to use the term "sub-state governments", given the distinction between State and Nation. However, due to the fact that it is generally accepted in literature, the expression "sub-national governments" will be used in this paper. In the same way, the term "non-central governments" will be used to refer to these entities, in contrast to "central governments".

2 The term "non-central government" should be understood in a broad way, meaning a constituent unit of a federal country or an administrative division of a unitary state.

3 On possible discussions about the nomenclature, see: Zabala 2000; Romero 2004. 
requires that members seek ways of meeting local and regional demands not fully met by the central government. Furthermore states' reduced participation in their national economies in the 1980s and 1990s with the spread of neo-liberal economic policy began to be seen as an important instrument for the improvement of sub-national public policies. This movement is facilitated, in the case of federations, because of greater autonomy granted by central governments; unlike what has been seen to occur in unitary states.

Also the evolution of the international system in recent decades has driven paradiplomacy. The beginning of international action by non-central governments took place in the larger context of the democratization of the international system; a process that began after the Second World War (Sassen 2001.) Therefore an important change occurred in the once exclusively inter-state system which had dominated the international arena since the $17^{\text {th }}$ century. Although states remain the primary actors in this scenario, the acceleration of international flows - or globalization - and the development of regional integration processes have facilitated the emergence of important new players to a once foreign sphere.

The processes of globalization and regional integration create favorable conditions for the increased action of sub-national governments in the foreign sphere. Waves of migration for example, bring about the need for non-central governments to deal with cultural and linguistic diversity that increase the probability of closer bonds with foreign institutions and governments. Furthermore, the expansion of multinational corporations has meant that sub-national governments need to develop policies focused on economic internationalization, preparing their population and territory for the arrival of foreign investments.

The changes accompany a corresponding change in the approach of international problem solving; moving from a state-centric approach to one welcoming input from constituent units. The perception that regional and local level governments must be included in problem-solving efforts related to these issues led to a greater consideration of these spheres in efforts of international agencies and organizations. ${ }^{4}$

There is a tendency for paradiplomacy to supplement the activities of non-central governments in their sphere of competence with the unique aspect that they go beyond national frontiers. In extremely rare cases, the international relations of sub-national governments go against the foreign policy of the federal government or encroach into jurisdictions outside of a given non-central government. ${ }^{5}$

4 Therefore, during the 1990s, the United Nations held large conferences which were drivers for sub-national governments, and, above all, the local powers were able to establish themselves on the international scene (Rodrigues 2004, p. 441). Along the same line, in 2000 , the United Nations launched the Goals of the Millenium, considered one of the most important programs currently run by the institution. Through this, the UN has sought to involve regional and local governments, understanding that the solution for the big problems affecting states today need to be dealt with at the sub-national level.

5 This kind of foreign relations by sub-national governments is called protodiplomacy and has been more widely studied in the autonomous regions of Spain (Segura 2004). 
In Brazil paradiplomacy started to move forward more firmly in the 1980s, with the redemocratization of the country after years of military dictatorship. ${ }^{6} \mathrm{~A}$ symbol of the new democratic phase, the federal constitution of 1988 formally entrenched the right of common citizens to participate in the democratic process. The constitution incorporated both the relevance of consensus and the need for the participation of minorities. However the constitution also brought considerable administrative and political decentralization through greater tax distribution and an extension of the sharing of competences between federal entities. There is a greater autonomy of member states and, ${ }^{7}$ since they gained greater autonomy over the budgets, a larger number of competing competences. ${ }^{8}$

During the 1980s, following the paths of the world economy and the crisis of the development-state based ideology of the 1970s; the Brazilian economy went through an important period of adjustments. Brazil joined the new wave of economic liberalism that affected most of the Western world. As part of the adaptation to this new context, the federal government started an intensified process of economic deregulation, the privatization of public corporations and opening to foreign capital. In practice, this meant a reduction of the nation state in domestic affairs and a greater opening to the international market.

During the transition to economic liberalism, a reduction in the economic and financial actions of the central government created a vacuum. This vacuum was then filled by the sub-national entities and municipalities of Brazil. The seizing of opportunities provided by foreign investment appeared as an appealing alternative to other options that were advanced to deal with the issues which were arising (Barreto 2004). Brazilian sub-national governments have being specially active in seeking international loans and attracting foreign investments by tax incentives for multinational enterprises.

There is some consensus in the literature about what promotes international organizations to seek constituent level input in federations. Michael Keating was one of the first scholars to define three general groups of such motivations that fit the Brazilian situation, these causes are economic, political and cultural (Keating 2004). In the economic sphere, it is sought after international funding, as well as foreign investments and increased exports of locally produced goods. In the political sphere, agreements

6 It is true that some international actions of member states can be seen since the 1960s. There was the protest of the then Governor of the State of Rio Grande do Sul against the federal government for not taking part in the negotiations for the creation of the Latin American Free Trade Association and also the creation of the International Relations Secretariat in the State of Minas Gerais. Although they were important initiatives bringing the theme of internationalization to sub-national governments, they were isolated initiatives.

7 The 1988 federal constitution included the municipalities as members of the Brazilian federation, inaugurating a three-way federal system.

8 This does not mean, however, that Brazil is a truly decentralized federation. With the constitution of 1988 there was a move towards decentralization, when compared to previous periods, but the country still has a strongly centralized structure. 
are made to empower local public policies and disseminate best practices as well as carry the needs of sub-national governments to the international system - through networks of cities and bilateral agreements, for example. In the cultural sphere, subnational governments seek agreements that deal with migratory flows and which allow greater visibility to increase tourism.

Therefore, it can be seen that the pragmatics of paradiplomacy in Brazil - as well as in other countries where this phenomenon occurs - can involve a variety of agreements from contracts to international agreements. There are different degrees of commitment taken on by sub-national governments which raises questions about the legal aspects of the phenomenon.

\section{Tendencies of Constitutionalization of Paradiplomacy in Federal States}

International law only recognizes as unquestioned legal entities the states and international organizations - as well as a few entities close to these two categories (Shaw, 2003). Therefore, from the traditional view of international relations, there is no clear answer as to what the legal reach of sub-national governments is the international system. To rectify this issue, governments should turn to national norms as guidelines to define acceptable state action (Pellet 2002). This depends essentially on the degree of decentralization of the federation: the higher decentralization is the greater the probability of constitutional permission for paradiplomacy.

The Brazilian federal constitution does not foresee international relationships between sub-national governments, the federal district (Brasilia, the federal capital) and municipalities (Rodrigues 2008, p. 1019). In spite of this, the practice of foreign interaction with states has become deeper and more widespread among the subnational governments. The distance between practice and law in the sphere of paradiplomacy has a reason. It is difficult to create an appropriate legal framework that can deal with the complexity of the process, as well as its dynamics.

However the constitutionalization of paradiplomacy may bring restrictions to the international action of the sub-national entities. Therefore, in understanding the obstacles of a possible constitutional reform, it is important to analyze the standards adopted by federal states in adapting their legal frameworks with regard to (a) the kind of norms utilized, and (b) the material competencies designated, as well as (c) the limits established.

a) Norms: By definition, the federal constitution is the basic document which deals with the division of competencies between federated entities; therefore, it should be the main instrument to define the possibility and the limits of paradiplomacy (Rezek 2005.) With paradiplomacy foreseen in the constitution, it follows the principle of legality, inherent to administrative law which means that all actions of the public administration should be guided by law. The federal constitution should establish the areas where involvement of the sub-national entities would be suitable and, therefore, underline the 
centralization of power-- whether in the federation itself, or in the member states (Moraes 1998, p. 28).

Therefore, in most cases, the rules regulating international actions by members of the federation have been done through constitutional amendments. That is what happened in Belgium, with the constitutional reform of 1993, in Argentina in 1994 and, in Austria in 2002. A different understanding of the issue occurred in the Mexican federation, which chose to normatize paradiplomacy through an infra-constitutional law. In spite of the outspoken disagreement of the local constitutionalists with regard to the suitability of this decree (Abraham 2007, p. 280). Since 1992 Mexico has had the "Law of Celebration of Treaties" which widens the possibility of international participation with some autonomy by sub-national entities. Therefore, although the Mexican constitution affirms the impossibility of international agreements by non-central governments, an infra-constitutional norm admits this possibility.

b) Material competences: With regard to the issues about which the federal subunits may deal with in international agreements, it is usually established that they may make agreements on any issue within their sphere of competence. The Swiss constitution, for example, foresees the possibility of agreements between cantons and foreign states, in which they must limit themselves to the competences of federated entities. The German constitution is similar, indicating the possibility of member states celebrating international agreements in the sphere of their attributions. The Austrian Constitution, which indicates that the Länder may sign treaties with states of neighboring Austria or with other states, as long as they are within the competences attributed to them.

To a lesser extent, there are cases in which federated entities only deal with issues related to their exclusive competences. This occurs often in Belgium. Although in theory the Belgian Constitution allows for the possibility of agreements by communities and regions on issues within their competence, in practice, these agreements mostly focus on issues of education and culture, which are exclusive competences of sub-national governments. In practical terms, there is in the Belgian case, a sharing of competences on treaties issues.

The fact is that, without exception, legal provisions dealing with paradiplomacy pigeon-hole state government into dealing with issues of low politics; like trade, culture and those issues that are not directly related to sovereignty or national security. This can be seen in the constitutional dynamics of the federated states, which attributes to the central government the competence to deal with issues related to high politics. ${ }^{9}$

c) Limits: The constitutionalization of paradiplomacy does not occur without precise limits. Besides the issue of delineating competences, there are also procedural limits for sub-national governments to operate internationally. The most common

9 There has been some discussion about the possibility of classifying issues as low politics and high politics, since that, in an interdependent world, they tend to overlap with some frequency, see Ripsman 2004. 
constraint is of prior approval of the federal sphere. The agencies responsible for approval vary. Some states grant the executive power; for example the ministry responsible for foreign affairs has the authority to approve or not approve a negotiation or agreement. In others, the Legislative branch has the power to approve these agreements.

This limit imposed by some constitutions - in fact most of them - has a negative implication on the dynamics of paradiplomacy. The international actions of non-central governments begin even before there is a constitutional reference about them - as in the Brazilian case. Therefore, when the matter becomes constitutionalized and begins to require that every agreement should be previously approved by a central government agency, the celerity of the movement is lost. Some interesting solutions have been found to counter-act this problem. In Austria, the federal government must be informed by the governor of the Land before negotiations of an international agreement are initiated and then it has eight weeks to issue a decision. If there is no refusal during this period, it is tacitly understood that the request has been approved, and the state government may start the negotiations.

Another interesting case is that of the United States. The federal constitution says that the federated subunits may have agreements abroad, with the stipulation that the state has the approval of U.S. Congress for the agreement to take effect. The interpretation of this condition was initially restrictive, in the understanding that Congress should be consulted about any foreign actions by non-central governments. The intensification of paradiplomacy increased the scope - which was possible mostly due to the fact that the United States is governed by a common law system. With the dramatic increase of the number of agreements signed by single states today, there is not full compliance with the constitutional requirement of a consultation to the U.S. Congress (Lessa 2002, p. 41.) Many of these agreements are carried out directly between the parties to save time. U.S. Congress itself, understanding the risk of its operations could be compromised due to the number of agreements to be approved, has interpreted that only agreements which interfere with security and the guidelines of national foreign policy should be examined (Branco 2006, p.71.)

The policy of approval works both ways as there can also be issues of compatibility with the foreign policy followed by central government. This fact is related to the classical view that the nation state should be seen as a unit in the international system. This would be mitigated by policies on paradiplomacy that did not follow the guidelines dictated by central government. In the same way, internal governability could be damaged if agreements of sub-national governments went against the interests of the federal government. This issue arises in commitments taken on by the federal state. The agreements should not fail to harmonize with previous obligations assumed by central government whether in the national or international spheres. 


\section{In search of a legally ordained paradiplomacy in Brazil}

In recent years, the discussion on the need to legally ordain paradiplomacy has led to an attempt to constitutionalize the matter as well as some efforts at infra-constitutional legal framing.

In 2005 the constitutional amendment proposal no. 475 was sent to the Brazilian congress. The amendment no. 475 regulated the action of member states, the federal district and municipalities internationally. It did so through an addition to the constitutional law that dealt with competences common to federated entities. If approved, the constitution would state that these entities could bring about acts and sign agreements or contracts with sub-national foreign governments, as long as the constitutional competences for each entity were followed and the competences which are exclusive to the union be avoided. The constitution, justice, and citizenship committee of the national congress argued that the lack of explicit permission in the constitution about international actions by federated members was not sufficient reason to forbid it. The argument of the committee, although contrary to the majority view on this issue, which states the need for the competences of federated entities to be stated in the constitution, prevailed and the constitutional amendment proposal was rejected.

This was followed by attempts of non-constitutional legal framing. There is a proposal in senate today ${ }^{10}$ substituting white paper supplementary law no. 98 from 2006. This proposal rules on the possibility of member states, municipalities and federal district to act in the foreign sphere through signing agreements, which should be examined previously by the Ministry of Foreign Affairs. It is difficult to imagine how approval could be attained with efficiency for Brazilian municipalities, which today number over 5,500 .

Besides the substitution proposal, there are two protocols in congress, signed by the Brazilian federal government with the governments of France and Italy that seek to provide a framework for paradiplomacy between the states in agreements. The protocols indicate the importance of this movement and establish possible modalities of the action of sub-national governments - in areas of their competence - as well as the need for prior consent of the Ministry of Foreign Affairs, for the signing of agreements.

\section{Consequences of the lack of legal framing}

The lack of legal framing of paradiplomacy has both positive and negative consequences in the Brazilian case. There a legitimate concern by the sub-national governments that, in inserting paradiplomacy in the legal framework, the limits are too wide and the process becomes limited. These are almost inherent consequences to phenomena that develop outside legal principles. To imagine that each negotiation or agreement carried out today at the initiative of sub-national governments has then to be submitted to the Ministry of Foreign Affairs or the national congress is very

10 As of the writing of this paper in July 2010. 
disturbing for those who are already part of the process and this is not because of the concern that the agreement might be refused. Paradiplomacy in Brazil, in spite of the lack of an actual legal framework, does not tend to usurp competences of other spheres or to act contrary to the foreign policy of the country. The greater concern is the amount of red tape that will bind down a process that ought to be dynamic in order to truly attain its objectives.

On the other hand, a negative consequence of the lack of constitutionalization of the phenomenon is the lack of guidance on the practice of sub-national international relations. Also, an important concern is the possibility that state and municipal public administration could have their actions questioned in court or in a court of auditors because they are beyond their constitutional competences. So far this has not occurred for the executive power ${ }^{11}$. However, it is necessary to observe that the forms of interaction of non-central governments in the international system have become sophisticated, which raises the possibility of some kind of inspection.

Another important issue related to the lack of a legal framework is the responsibility for international agreements that are not upheld. In the Brazilian case, it is not clear who would be responsible for default on agreements made by sub-national governments. With the possibility of new government cycles, this hypothesis is especially serious because of the possible default on commitments assumed by previous governments.

\section{Conclusion}

As happened in other countries, Brazil faces a troublesome dichotomy on the constitutionalization of paradiplomacy. There is no easy answer to the issue since the contours of possible legislation on the theme can vary stalling the process. It is true that the debates on the issue in Brazil are still at too early a stage to draw up an adequate legal framing. Carrying out a constitutional reform that is coherent both with the Brazilian legal system and the demands of the federal government and of the subnational governments seems unlikely at this time. This does not, however, reduce the importance of deepening the dialogue. On the contrary, it reaffirms the need.

11 There are two lawsuits by the Rio Grande do Sul Public Prosecutor's Office in Novo Hamburgo, questioning travel by town counselors accompanying the mayor on trips abroad. One of them is against 24 counselors and ex-counselors for mismanagement of public resources because of trips in 2004, 2005 and 2007. Besides those that benefited with their expenses being paid, the Public Prosecutor's Office also targets counselors who voted in the plenary in favor of the trips to France, China and the Iberian Peninsula. According to the counselors, the missions had the purpose of drawing together Brazilian and foreign companies and getting to know the technology of the countries visited. Another lawsuit refers to trips to India in 2008. The Public Prosecutor's Office does not question the possibility of municipal authorities defending local interests in the foreign sphere, but the need for representatives from the Legislative to do so (Dutra 2008). 
Paradiplomacy is an important tool to reaffirm the idea of a national project that seeks greater development and greater autonomy for its subunits. In this context, being able to rely on institutional and legal frameworks that extend the chances of bringing this into effect is a way of assisting in the balance of federative agreement. 


\section{References}

[1] Abraham, L. 2007, "La cooperación descentralizada pública en México: La hora ha llegado" in: Anuario de la cooperación descentralizada 2006. Observatorio de Cooperación Descentralizada Unión Europea - América Latinal, Montevideo.

[2] Barreto, M. 2001, Dimensões Recentes da Gestão Estratégica de Governos Subnacionais: Inserção Internacional e Integração regional. Seminário: O Estado Contemporâneo na Economia Mundial, Rio de Janeiro.

[3] Branco, Á. 2006, A paradiplomacia como forma de inserção dos entes não centrais no cenário internacional, Universidade de Brasília. Programa de Mestrado em Direito.

[4] Dutra, C. 2008, "Vereadores e ex-vereadores são acionados pelo MP" in: Clipping do Ministério Público do Rio Grande do Sul, retrieved from: http://www.mp.rs.gov.br/imprensa/clipping/id70014.htm.

[5] Keating, M. 1999, "Regions and international affairs: motives, opportunities and strategies" in: Aldecoa, F., Keating, M. (eds), Paradiplomacy in Action: The Foreign Relations of Sub-national Governments. London: Frank Cass, p. 1-17.

[6] Lessa, J. 2002, A paradiplomacia e os aspectos legais dos compromissos internacionais celebrados por governos não-centrais. Brasília: MRE.

[7] Moraes, A. 1998, Direito Constitucional, Editora Atlas, São Paulo.

[8] Pellet, A. et al. 2002, Droit International Public, L.G.D.J, Paris.

[9] Ripsam, N. 2004, "False Dichotomy: When Low Politics is High Politics", paper presented at the annual meeting of the International Studies Association, Montreal, Quebec, Canada.

[10] Rezek, J. 2005, Direito Internacional Público, Editora Saraiva, São Paulo.

[11] Rodrigues, G. 2004, "A inserção internacional de cidades: notas sobre o caso brasileiro" in Vigevani, T. et al (eds.), A dimensão subnacional e as relações internacionais, EDUC/UNESP/EDUSC/FAPESP, São Paulo, p.441-462.

[12] Rodrigues, G. 2008, Relações internacionais federativas no Brasil, Dados, Rio de Janeiro, p.1015-1034.

[13] Romero, M. 2004, "Uma aproximación conceitual y contextual de la cooperación descentralizada" In: Zúñiga, V.; Romero, M. (eds.), Tejiendo lazos entre territórios: la cooperación descentralizada local Unión Europea-América Latina, Valparaíso, p.19-51.

[14] Sánchez, R. 2004, "La conformación federal del Estado y su implicación en los procesos de integración" in Vigevani, T. et al (eds.), A dimensão subnacional e as relações internacionais, EDUC/UNESP/EDUSC/FAPESP, São Paulo

[15] Sassen, S. 2001, "El Estado y la nueva geografia del poder" in Perdiendo El control? La Soberania en la Era de la Globalizacion, Edicions Bellaterra p. 48-72

[16] Segura, C. 2004, "La participación de las comunidades autónomas españolas en las relaciones internacionales. Reflexiones sobre la presencia internacional de 
las comunidades autónomas históricas" in Vigevani, T. et al (eds.), A dimensão subnacional e as relações internacionais, EDUC/UNESP/EDUSC/FAPESP, São Paulo

[17] Shaw, M. 2003, International Law, Cambridge University Press, Cambridge.

[18] Soldatos, P., Michelmann, H. (eds.) 1990, Federalism and international relations: the role of sub-national units, Claredon Press, Oxford.

[19] Vigevani, T. 2006, Problemas para a atividade internacional das unidades subnacionais: São Paulo e o contexto brasileiro. Cadernos, São Paulo, p.12-29.

[20] Zabala, I. 2000, “¿Qué sentido tiene hablar de paradiplomacia? Una encuesta intertextual en torno a un neologismo polisémico" in Aldecoa, F., Keating M. (eds). Paradiplomacia: las relaciones internacionales de las regiones. Marcial Pons- Ediciones Jurídicas y Sociales, Madrid. 